\title{
Fetal Skull
}

National Cancer Institute

\section{Source}

National Cancer Institute. Fetal Skull. NCI Thesaurus. Code C34172.

The development of the skull after the eleventh week of gestation until the time of birth. 